\title{
Frequency and risk factors of neural tube defects in Samsun province
}

\section{Samsun illinde nöral tüpp defekti sıklığl ve nöral tüp defekti için risk faktörleri}

\author{
Aslihan Sanri 1, Metin Karayel 2, Ummet Abur 3, Engin Altundag 3, Omer Salih Akar 3, Handan \\ Celik ${ }^{4}$, Migraci Tosun 4, Canan Aygun 2, Gonul Ogur 1,3
}

Cocuk Genetik Bilim Dalı, ${ }^{2}$ Cocuk Sağlı̆ı Ve Hastalıkları Anabilim Dalı, ${ }^{3}$ Tıbbı Genetik Anabilim Dalı, ${ }^{4}$ Kadın Sağlığı Ve Hastalıkları Anabili Dalı, Ondokuz Mayıs Üniversitesi Tip Fakültesi, Samsun, Turkey

Corresponding author: Aslıhan Sanı1, MD., Cocuk Genetik Bilim Dalı, Ondokuz Mayıs Üniversitesi Tip Fakültesi, Samsun, Turkey

E-mail: aslihanaltunoglu@gmail.com

Received/Accepted: July 07, 2018 / December 18, 2018

Conflict of interest: There is not a conflict of interest.

\section{SUMMARY}

Objective: Neural tube defects (NTD) are a group of severe human congenital malformations and complex disorders appear to be affected by multiple factors, both genetic and environmental contributions.

To asses the frequency of NTD in Samsun province and investigate the relationship between NTD and sociodemographic properties of families, maternal eating habits, maternal serum folic acid, and vitamin B12 levels.

Method: The women who gave birth to infants with NTDs and whose pregnancies were terminated due to having fetuses with NTDs between July 2007 and September 2008 were included in the study.The frequency of NTD was calculated from medical records for Samsun province.Sociodemographic characteristics,nutritional status, obstetric histories, teratogen exposure and vitamin B12 and folic acid levels of study group were compared with controls.

Results: In the study period, 63 fetuses with isolated NTD were noted. The frequency of NTD in Samsun region was $\%$ o3,4. In the study group, family incomes, maternal education and consumption of meat, milk, egg, cheese, vegetable, and legumes were lower than the control group $(\mathrm{p}<0.05)$. Sharing of the house with grandparents, unemployment rate, rate of febrile diseases, use of antipyretics, exposure to radiation were higher $(\mathrm{p}<0.05)$ in study group. Both maternal serum vitamin B12, folic acid in NTD group were lower than controls $(\mathrm{p}<0.05)$.

Conclusions: The frequency of NTD in Samsun region was relatively high. NTD was more frequent in individuals with poor maternal education, low income, and insufficient nutrition. Low serum vitamin B12 and folic acid levels posed an increased risk for NTD. The importance of the vitamin supplements during pregnancy is to be better appreciated by the health authorities as well as the families.

Keywords: neural tube defects, nutrients

\section{ÖZET}

Amaç: Nöral tüp defektleri (NTD), hem genetik hem de çevresel katkılar gibi pekçok faktör nedeni ile oluşan,

kompleks ve ağır konjenital malformasyonladır.

Bu çalışmada Samsun ili için NTD sıklığını belirlemek, ailelerinin sosyodemografik özellikleri, maternal beslenme alışkanlıkları, maternal serum folik asit ve vitamin B12 düzeyleri ile NTD arasındaki ilişkiyi değerlenmek amaçlandı. Yöntem: Temmuz 2007 ile Eylül 2008 tarihleri arasında NTD'li bebek doğuran ve NTD'li fetus nedeniyle gebelikleri sonlandırılan kadınlar çalışmaya dahil edildi. Samsun ilindeki tıbbi kayıtlardan NTD sıklığı hesaplandı. Çalışma grubunun sosyodemografik özellikleri, beslenme durumu, obstetrik öyküleri, teratojen maruziyeti ile vitamin B12 ve folik asit düzeyleri kontrollerle karşılaştırıldı.

Bulgular: Çalışma döneminde 63 izole NTD'li fetus kaydedildi. Samsun bölgesinde NTD sıklığ \% o 03,4 idi. Çalışma grubunda, aile gelirleri, anne eğitimi, et, süt, yumurta, peynir, sebze ve baklagillerin tüketimi kontrol grubundan daha düşüktü $(p<0.05)$. Çalışma grubunda evin büyükanne ve büyükbabalarla paylaşılması, işsizlik oranı, ateşli hastalıkların 
oranı, ateş düşürücü madde kullanımı, radyasyona maruz kalma oranı daha yüksekti $(\mathrm{p}<0.05)$. NTD grubunda maternal serum vitamin B12 ve folik asit düzeyleri kontrollerden daha düşüktü ( $p<0.05)$.

Sonuç: Samsun bölgesinde NTD sıklı̆ı̆ nispeten yüksekti. Yetersiz anne eğitimi, düşük gelir ve yetersiz beslenme olan bireylerde NTD daha sıktı. Düşük maternal serum vitamin B12 ve folik asit düzeyleri NTD için artmış risk oluşturdu. Gebelik sırasında vitamin takviyelerinin önemi, sağlık yetkilileri ve aileler tarafından daha iyi değerlendirilmelidir.

Anahtar sözcükler: nöral tüp defektleri, besin maddeleri

\section{INTRODUCTION}

Neural tube defects (NTD) are a group of severe human congenital malformations caused by the incomplete closure of neural tube within about 28 days following conception ${ }^{1}$. NTDs are the second most common congenital malformation following congenital heart defects and can lead to miscarriage, infant death and serious life-long disability ${ }^{2,3}$. The worldwide prevalence of NTDs ranges from $0.57 \%$ and $13.87 \%{ }^{2}$.

NTDs are complex disorders and appear to be affected by multiple factors, both genetic and environmental contributions ${ }^{1}$. Among the environmental factors, geographical settlements, ethnicity, socio-economic status, nutritional habits, trace elements and vitamin deficiencies are important ${ }^{3}$. A number of maternal factors such as obesity, diabetes mellitus, hyperthermia, drug exposure have been found to be implicated in the etiology of NTDs ${ }^{2}$. Folic acid and vitamin B12, as crucial factors for metabolic pathways, have

\section{MATERIAL AND METHODS}

\subsection{Patients}

The women who gave birth to infants with NTDs and whose pregnancies were terminated due to having fetuses with NTDs, in the Samsun province between July 2007 and September 2008 were included in the study. The cases who had additional anomaly were not included. As a control group, women who had healthy pregnancies according to ultrasonography (USG) records and who gave birth to healthy infants were chosen.

\subsection{Sociodemographic Characteristics, Nutritional Status and Possible Teratogenic Factors}

Cases in the study group were assessed by face to face interviews about their sociodemographic characteristics, nutritional status, obstetric histories and teratogen exposure.

Maternal and paternal age, educational level and profession, accommodation status, income, been extensively studied and demonstrated that they have important roles in the development of NTDs ${ }^{2,3}$. Since the introduction of folic acid fortification in staple food, many countries have reported overall declines in NTDs incidence. However, there are still enourmous numbers of new NTD cases and the cause remains unclear ${ }^{1}$.

In Turkey, the prevalence of NTDs ranges between $1.5 \%$ and $6,3 \%$. However, the studies for NTDs prevalence in Black Sea Region is limited. In the study about the prevalence of NTDs in Samsun province it was found out to be $3.8 \%{ }^{3}$.

In the present study, we aimed to ascertain the NTD prevalence in Samsun province, identify the relationship between NTDs and serum folic acid and vitamin B12 levels, socio-demographic features of the families, nutritional habits of the mothers and find out other related factors in the etiology of NTDs.

housing condition and consanguinity were evaluated as sociodemographic characteristics. Maternal occupation status was grouped as house wife, civil servant, self-employed and worker whereas paternal professions were classified as civil servant, self-employed, worker and unemployed. Educational status of parents was classified as illiterate, literate, primary school graduate, secondary school graduate, high school graduate and college graduate. Income levels of the families were grouped as lower or upper than the minimum wage. In addition, the level of income per capita was calculated according to the number of individuals living at home.

In the maternal obstretric history; the number of gravitiy, miscarriage, stillbirth and abortions, previous pregnancy with NTD and close relatives with history of NTD-pregnacy were asked. Maternal febrile illness, drug usage, radiation exposure, ciggarette smoking in the first trimester and maternal pre-pregnancy obesity were evaluated as possible teratogenic factors.

Questions evaluating the maternal nutritional status were organised according to the literature ${ }^{4}$. 
Mothers were asked how often they consumed meat, milk, yogurt, eggs, vegetables, fruits, cereals, cheese and legumes during their pregnancies. The answer categories were arranged as never, monthly, twice per month, three times per month, once per week, twice per week, three times per week, four times per week, five times per week and more than five times per week. Each answer was scored between 1 and 10 respectively.The same questionnaire was applied to the control group as well.

\subsection{Levels of Serum Vitamin B12 and Folic Acid}

To investigate the relationship between NTD maternal vitamin B12 and folic acid levels, the third group of non-pregnant and healty women selected from the normal population was added to the study as a third group. Blood samples for vitamin B12 and folic acid were taken before breakfast from all of the groups. Vitamin B12 level was measured by immunoassay method in RocheHitachi E 170 device and the folic acid level was measured by immunoassay method in immulite 2500 BIO-DER device.

Approval of the local ethics committee for the study was obtained (Decision no: 2007/151).

\subsection{Statistical Analysis}

Statistical evaluation was performed using SPSS 13.0 (Statistical Program in Social Sciences) computer program. The data was expressed as number, percentage, average and standard error of average. Comparisons between groups of statistical analysis methods were made with the significance test "Mann-Whitney-U" between the two means. Categorical data were compared by "chi-square". In statistical tests $\mathrm{p}$ values below 0.05 were statistically significant.

\section{RESULTS}

According to the official records, there were a total of 13974 live births, still births and abortions in Samsun province during the eight months of the research period. A total 65 cases with NTDs were detected. And two of them were excluded due to accompanying anomalies. 48 of the remaining 63 isolated NTD patients were from Samsun province. The NTD frequency for Samsun province was calculated as $3,43 \%$.

34(52.4) of the NTD cases were female and 29 $(47.6 \%)$ of them were male.33 of the cases (52.4\%) had spina bifida, 26 of them had (41.3\%) meningomyelocele, 7 had (11.1\%) meningocele, $27(42.9 \%)$ of them were with anencephaly and finally $3(4.8 \%)$ of them were with encephalocele.

The sociodemographic features of the study and control group are shown in Table 1. The average maternal age and distribution of ages, paternal education levels and maternal occupations were similar in both groups. The number of high school graduate mothers was more in the control group and the maternal education levels of the control group was evaluated as higher than as in the study group. In the study group rates of paternal unemployment and living with parents were higher whereas monthly family income amounts and monthly per capita income in the study group were lower . 
Table 1. Demographic and obstetric characteristics of subjects and their relatives with NTDs

\begin{tabular}{|c|c|c|c|}
\hline Factors & Cases n(\%) & Controls n(\%) & $\mathbf{p}$ \\
\hline Maternal age (years) & $27.2 \pm 5.54(18-39)$ & $26.5 \pm 5.31(18-40)$ & $>0.05$ \\
\hline $\begin{array}{l}\text { Maternal education level } \\
\text { Non literate } \\
\text { Literate } \\
\text { Primary school graduate } \\
\text { Middle school graduate } \\
\text { High school graduate } \\
\text { University graduate }\end{array}$ & $\begin{array}{l}4(6.3) \\
1(1.6) \\
41(65.1) \\
9(14.3) \\
6(9.5) \\
2(3.2)\end{array}$ & $\begin{array}{l}- \\
- \\
48(49.4) \\
11(11.3) \\
34(35) \\
4(4.1)\end{array}$ & $\begin{array}{l}>0.05 \\
>0.05 \\
>0.05 \\
>0.05 \\
<\mathbf{0 . 0 5} \\
>0.05\end{array}$ \\
\hline $\begin{array}{l}\text { Maternal periconceptional } \\
\text { occupation } \\
\text { Housewife } \\
\text { Worker } \\
\text { Officer } \\
\text { Self-employment }\end{array}$ & $\begin{array}{l}58(92.1) \\
2(3.2) \\
2(3.2) \\
1(1.6)\end{array}$ & $\begin{array}{l}85(87.6) \\
4(4.1) \\
3(3.1) \\
5(5.2)\end{array}$ & $\begin{array}{l}>0.05 \\
>0.05 \\
>0.05 \\
>0.05\end{array}$ \\
\hline $\begin{array}{l}\text { Paternal occupation } \\
\text { Unemployed } \\
\text { Worker } \\
\text { Officer } \\
\text { Self-employment } \\
\end{array}$ & $\begin{array}{l}29(46) \\
13(20.6) \\
2(3.2) \\
19(30.2) \\
\end{array}$ & $\begin{array}{l}12(12.4) \\
23(23.7) \\
19(19.6) \\
43(44.3) \\
\end{array}$ & $\begin{array}{l}<\mathbf{0 . 0 5} \\
>0.05 \\
>0.05 \\
>0.05 \\
\end{array}$ \\
\hline $\begin{array}{l}\text { Paternal education level } \\
\text { Non literate } \\
\text { Literate } \\
\text { Primary school graduate } \\
\text { Middle school graduate } \\
\text { High school graduate } \\
\text { University graduate }\end{array}$ & $\begin{array}{l}1(1.6) \\
- \\
39(61.9) \\
10(15.9) \\
11(17.5) \\
2(3.2)\end{array}$ & $\begin{array}{l}- \\
- \\
44(45.3) \\
20(20.6) \\
21(21.6) \\
12(13.0)\end{array}$ & $\begin{array}{l}>0.05 \\
>0.05 \\
>0.05 \\
>0.05\end{array}$ \\
\hline $\begin{array}{l}\text { Montly income } \\
<500 \text { YTL } \\
<500 \text { YTL }\end{array}$ & $\begin{array}{l}20(31) \\
43(68.2)\end{array}$ & $\begin{array}{l}11(11.3) \\
86(88.7)\end{array}$ & $\begin{array}{l}<0.05 \\
<0.05\end{array}$ \\
\hline $\begin{array}{l}\text { Montly per capita income } \\
\text { (YTL) }\end{array}$ & $\begin{array}{l}176.7 \pm 162.9 \\
1000)\end{array}$ & $\begin{array}{l}293.4 \pm 162.9 \\
(25-1250)\end{array}$ & $<0.05$ \\
\hline $\begin{array}{l}\text { Housing situation } \\
\text { Sit at the rent house } \\
\text { Sit at the parents' house } \\
\text { Sit at the own house }\end{array}$ & $\begin{array}{l}19(30.2) \\
37(58.7) \\
7(11.1)\end{array}$ & $\begin{array}{l}39(40.2) \\
18(18.6) \\
40(41.2)\end{array}$ & $\begin{array}{l}>0.05 \\
<\mathbf{0 . 0 5} \\
>0.05 \\
\end{array}$ \\
\hline $\begin{array}{l}\text { Consanguinity } \\
\text { Yes } \\
\text { No }\end{array}$ & $\begin{array}{l}12(19) \\
51(81)\end{array}$ & $\begin{array}{l}8(8.2) \\
89(91.8)\end{array}$ & $\begin{array}{l}>0.05 \\
>0.05\end{array}$ \\
\hline $\begin{array}{l}\text { Body mass index of mother } \\
\text { Underweight } \\
\text { Normal } \\
\text { Overweight } \\
\text { Obese } \\
\end{array}$ & $\begin{array}{l}8(12.7) \\
29(46) \\
16(25.4) \\
10(15.9)\end{array}$ & $\begin{array}{l}16(16.5) \\
62(6.9) \\
12(12.4) \\
7(7.2)\end{array}$ & $\begin{array}{l}>0.05 \\
>0.05 \\
<\mathbf{0 . 0 5} \\
>0.05\end{array}$ \\
\hline $\begin{array}{l}\text { Maternal obsretric history } \\
\text { Pregnancy number } \\
\text { Spontaneous abortion } \\
\text { Stillbirth } \\
\text { Previous NTD of mothers and } \\
\text { relatives }\end{array}$ & $\begin{array}{l}3 \pm 1.63(1-9) \\
14(22.3) \\
6(10.5) \\
10(15,8)\end{array}$ & $\begin{array}{l}2 \pm 1.16(1-5) \\
19(19.5) \\
4(4.1) \\
-\end{array}$ & $\begin{array}{l}>0.05 \\
>0.05 \\
>0.05 \\
<\mathbf{0 . 0 5}\end{array}$ \\
\hline $\begin{array}{l}\text { Teratogenic factors } \\
\text { Febril illness } \\
\text { Drug usage } \\
\text { Cigarette smoking } \\
\text { Radiation exposure } \\
\text { Alcohol comsumption }\end{array}$ & $\begin{array}{l}18(28.6) \\
32(50,7) \\
4(6.3) \\
4(6.3) \\
-\end{array}$ & $\begin{array}{l}11(11.3) \\
19(19,5) \\
4(4.1) \\
- \\
-\end{array}$ & $\begin{array}{l}<\mathbf{0 . 0 5} \\
<\mathbf{0 . 0 5} \\
>0.05 \\
>0.05 \\
-\end{array}$ \\
\hline
\end{tabular}

The mothers in the study group had more febrile illness and drug exposure in the prenatal period. Common medications were antipyretics $(26.9 \%)$ antibiotics $(6.3 \%)$ and antiemetics (6.3\%.) None of the mothers used alcohol during pregnancy in both groups. Cigarette smoking during pregnancy and radiation exposure were not significantly different between 2 groups.

The comparison of nutrient intake of the study and control group is shown in Table 2. Control group consumed meat, milk, eggs, vegetables, cheese 
and legumes more often $(\mathrm{p}<0,05)$ than the study group did. Yogurt, fruits, bread, and grains consumption did not seem to have a significant difference between two groups.
Mothers in group 1 were found to have lower level Vitamin B12 and folic acidthan of the ones in groups 2 and $3(\mathrm{p}<0.05)$ (Table 3$)$.

Table 2. Comparison of Nutrient Intake Scale of Study and Control Group

\begin{tabular}{|l|l|l|l|}
\hline & Study group $(\mathbf{n = 6 3})$ & Control group(n=97) & $\mathbf{p}$ \\
\hline Meat & $3.6 \pm 1.8$ & $5.7 \pm 2.11$ & $\mathbf{p}<\mathbf{0 . 0 5}$ \\
Milk & $3.5 \pm 3.4$ & $5.7 \pm 3.4$ & $\mathbf{p}<\mathbf{0 . 0 5}$ \\
Yogurt & $8.1 \pm 2.4$ & $8.6 \pm 2.1$ & $\mathrm{p}>0.05$ \\
Egg & $6.0 \pm 3.3$ & $7.2 \pm 3.2$ & $\mathbf{p}<\mathbf{0 . 0 5}$ \\
Vegetables & $8.3 \pm 1.95$ & $9.1 \pm 1.6$ & $\mathbf{p}<\mathbf{0 . 0 5}$ \\
Fruits & $9.0 \pm 1.5$ & $9.3 \pm 1.4$ & $\mathrm{p}>0.05$ \\
Bread & $9.7 \pm 0.7$ & $9.8 \pm 0.6$ & $\mathrm{p}>0.05$ \\
Grains & $6.7 \pm 1.9$ & $6.9 \pm 1.7$ & $\mathrm{p}>0.05$ \\
Cheese & $8.2 \pm 2.6$ & $8.9 \pm 2$ & $\mathbf{p}<\mathbf{0 . 0 5}$ \\
Legumes & $5.0 \pm 1.9$ & $5.9 \pm 2$ & $\mathbf{p}<\mathbf{0 . 0 5}$ \\
\hline
\end{tabular}

Table 3. Mean Values of Serum Folic Acid, Vitamin B12 of Women with NTD-pregnancies, Normal Pregnancies and Normal Population

\begin{tabular}{|l|c|c|c|c|}
\hline & $\begin{array}{c}\text { Study } \\
\text { group } \\
\text { (group 1) } \\
\mathbf{n = 2 0}\end{array}$ & $\begin{array}{l}\text { Normal pregnant } \\
(\text { group 2) n=38 }\end{array}$ & $\begin{array}{l}\text { Normal population } \\
\text { (group 3) n=78 }\end{array}$ & p \\
\hline $\begin{array}{l}\text { Vitamin B12 } \\
(\mathbf{p g} / \mathbf{m l})\end{array}$ & $143.1 \pm 72.6$ & $183 \pm 72.5$ & $279 \pm 99.7$ & $<\mathbf{0 . 0 5}$ \\
\hline $\begin{array}{l}\text { Folic acid } \\
(\mathbf{n g} / \mathbf{m l})\end{array}$ & $7.6 \pm 5.3$ & $11.2 \pm 6.2$ & $8.5 \pm 3.4$ & $<\mathbf{0 . 0 5}$ \\
\hline
\end{tabular}

\section{DISCUSSION}

Neural tube defects are one of the most severe congenital anomalies and epidemiological data show that the incidence varies according to regional and demographic characteristics ${ }^{5}$. The inadequacy of the health record system in Turkey limits the information about the frequency of the various congenital malformations and leads to difficulties in carrying out the new frequency studies.

In various studies the frequency of NTDs in Turkey was found to be in between 1.5\%o-6.3 $\%{ }^{6-9}$. These values show that NTD prevalence in our country is higher than as in Europe and in the USA. A study in Samsun province was conducted in 1988 by Yesilipek in Samsun and the frequency of NTDs was found to be 3.84\% , however in this study only the alive born infants were screened. The number of $3.43 \%$ which was found in our study includes all the isolated NTDs that were detected in the newborn or pregnancy period. It may be considered as, at the time of the study that was done 20 years ago in Samsun, prenatal diagnosis opportunities were limited. Thus NTD-pregnancies were rarely detected in the prenatal period and the numbers of medical termination due to NTDs was limited at the mentioned time. Nowadays, because of the increased feasibility of prenatal diagnostics opportunities and the relatively more convenient access to the medical services in our study, only $17(27 \%)$ of the cases appeared as newborn infants and for the remaining 46 cases, pregnancies were medically terminated in various periods of pregnancy. It can be seen that in the mentioned time there was not a change in the frequency of NTDs in our city. The fact that none of the women in our study had used folic acid before pregnancy and during the first 
month of pregnancy as suggested may explain why the frequency of NTDs is not reduced.

The maternal economic status, age, convenience of health services, dietary habits and lifestyle before and during pregnancy seem to be crucial for both mothers' and the infants' health ${ }^{10,11}$ Even in some studies, it is stated that NTDs risk is very high in young age and old age mothers. likewise, in our study Mandiracioğlu et al. found that there was no difference in terms of age between control and NTD group ${ }^{12}$. The importance of maternal education level is highlighted in many publications on the development of NTDs. Farley et al.) reported that a low maternal education level may be an important indicator of having a child with NTDs ${ }^{13}$. Mandıracıoglu et al. found that the level of education at the mothers of NTD-infants was significantly lower than the of control group mothers ${ }^{12}$. Similarly, in our study, it was seen that the education level of the mothers with NTD cases was lower than that of the control mothers. In some studies, it is stated that the paternal occupation is also important in the development of NTDs. Mutchinic et al. found that more fathers of children with NTDs were working in masonry than of the healthy children's fathers and they corresponded this to a low socioeconomic level ${ }^{14}$. Similarly, in our study, the rate of the unemployed fathers of NTD-children was higher than in the control group. As a sign of low socioeconomic level, the monthly incomes of the study group families and per capita income were also low.

Maternal obesity is seen as one of the risk factors for NTDs. Consumption of foods containing sucrose with the high glycemic index is reported to pose a risk for NTDs, especially in obese women ${ }^{15}$. Richards et al. had seen that mothers with anencephaly pregnancies were found to be overweight ${ }^{16}$.

Rasmussen et al. found that mildly overweight ladies had 1.22 times, obese had 1.7 times and morbid obese had 3.3 times more NTD risk than normal weight ladies ${ }^{17}$. In our study, mild obese was higher in the study group than the control group.
As teratogenic factors in the formation of NTDS smoking and alcohol consumption, febrile illness during pregnancy, and medication used in pregnancy were questioned. Cadmium in the cigarette has been shown to cause anencephaly, and nicotine has been shown to cause embryonic apoptosis in mice ${ }^{18}$. The usage of antiepileptic drugs and folic acid antagonists in pregnancy has been shown to cause NTD 19-21. Suarez et al. observed the relationship between smoking and alcohol consumption and NTD development, they found that the ones who smoked more than half a pack of cigarettes per day had 4 times more increased risk of NTDs ${ }^{18}$, whereas they did not find any correlation for alcohol. In our study, none of the mothers consumed alcohol besides, there was no difference in terms of smoking between the control and the study groups in the first trimester. It has been reported that infectious diseases causing high body temperature caused fetal losses and various malformations in animals ${ }^{22}$. Lynberg et al. reported that Influenza-like infections during pregnancy and exposure to febrile illness and the usage of antipyretic drugs increased the risk of NTDs ${ }^{23}$. Likewise, in our study, in the study group the frequency of febrile illnesses and usage of antipyretics during pregnancy were meaningfully high than that in the control group. In our study, there were no patients that had antiepileptics or folic antagonist medicines that are known to cause NTDs.

One of the prominent environmental factors influencing the formation of NTDs is the nutritional status before and during pregnancy. Mandıracıoğlu et al. found that mothers of NTD cases consumed fewer milk products, fruits, vegetables, meat, and bread than their control group in their study accomplished in Izmir ${ }^{12}$. Similar results were obtained in our study, determining that the consumption of vegetables, meat, milk and eggs of NTD-pregnant mothers was found to be less than that of the control group. Zhang et al. found that women who had NTDpregnancies consumed less meat, eggs, fresh vegetables, fruits and fresh potatoes when compared to control group ${ }^{24}$. 
In addition to folic acid, vitamin B12 has been the most emphasised factor for the development of NTDs. Kirke et al. reported that low folic acid and vitamin B12 levels are independent risk factors for NTDs ${ }^{25}$. Groenen et al. with their study involving 445 women having NTD-infants found that vitamin B12 levels were lower than those in the control group, which had led 3.5 times higher risk for NTDs ${ }^{26}$. Regarding the studies, it is thought that vitamin B12 plays a role in the etiology of NTDs along with folic acid thus, vitamin B12 supplementation besides folic acid supplementation in pregnancy came into question ${ }^{27-30}$. Serum folic acid and vitamin B12 levels in the study group were found to be significantly lower than those in the control group in our study. A similar study has not been done previously researching the Black Sea region.

The efficacy folic acid used in the periconceptional period to reduce the risk of pregnancy with NTDs is indisputable today. This information has been transmuted into the health policy of many countries. Enriching the nutrients with additional folic acid is seen as an important approach for reducing the frequency of NTDs in our country, where unplanned pregnancies are common. Moreover, it must be emphasized that folic acid enrichment of food is partially effective and that folic acid tablets should be used.

In conclusion, we have observed that the frequency of NTDs in Samsun province is higher than many regions of Turkey. We have identified that the NTDs are more common in individuals with lower education, income, occupation and nutritional status. We have obtained results that low serum vitamin B12 and folic acid levels are associated with increased risk for NTDs. As vitamin B12 is required for folic acid to be processed in the cell, we thought that those who have vitamin B12 deficiency before pregnancy should have vitamin B12 treatment with folic acid. Regarding that the pregnants in both study and control groups did not have vitamin supplements in the suggested period, so we have reached the conclusion that the mothers did not know the importance of vitamin supplements sufficiently. In light of all these findings we have concluded that transformation of health policy to provide educational programs for expectant mothers to receive adequate folic acid before pregnancy and implementing preventive medicine practices in high-risk areas such as the Black Sea region would make an important contribution to preventing NTDs

\section{REFERENCES}

1. Detrait ER, George MT, Etchevers CH, et al. Human neural tube defects: Developmental biology, epidemiology, and genetics. Neurotoxicology and teratology 2005; 27: 515524.

2. Nikkila A, Rydhström H, Kallen B. The incidence of spina bifida in Sweden 1973-2003: The effect of prenatal diagnosis. European Journal of Puplic Health 2006; 16(6): 660-662

3. Li Z, Ren A, Zhang L, Ye R, Li S, Zheng J, Hong S, Wang $\mathrm{T}$, Li $\mathrm{Z}$. Extremely high prevelance of neural tube defects in a 4-county area in shanxi province, China. Birth Defects Research 2006; 76 (Part A): 237-240

4. Block G, Gillespie C, Rosenbaum HE,et al: A Rapid Food Screener to Assess Fat and Fruit and Vegatable İntake. AM J Prev Med 2000; 18(4): 284-288

5. Tunçbilek E. Türkiye'deki yüksek nöral tüp defekti sıklığını ve önlemek için yapılabilecekler. Çocuk Sağlığı ve Hastalıkları 2004; 47: 79-84.

6. Akar N, Çavdar A and Arcasoy A: High Incidence of Neural Tube Defects in Bursa, Turkey. Pediatric and Perinatal Epidemology 1998; 2: 89-92

7. Say B, Tunçbilek E, Balcı S,et al. Incidence of congenital malformations in a sample of the Turkish population. Hum Hered 1973; 23: 434441

8. Mocan H, Bozkaya H, Özbay G, et al. Neural Tube Defects in eastern Black Sea region in1990. Pediatr Perinat Epidemiol 1992; 6: 465

9. Himmetoğlu O, Tiras MB. The incidence of congenital malformation in a Turkish population. Int J Gynecol Obstet 1996; 55: 117-121.

10. Suitor CW. Nutrition fo rwomen in their child bearing years: a review of thel iterature and a summary of expert recommendations. Nutr Clin Care 1999; 2: 11-45.

11. Bussel G, Marlow N. The dietary beliefs and attrtudes of women who have had a low -birth weight baby: a retrospective preconception study. J Hum Nutr Dietet 2000; 13: 29-39 
12. Mandıracıoğlu A, Ulman İ, Lüleci E, Ulman C. The incidence and risk factors of neural tube defects in İzmir, Turkey: a nested case-contro lstudy. TheTurkish of Pediatrics 2004; 46: 214220

13. Farley TF, Hambidge SJ, Daley MF. Assosiation of low maternal education with neural tube defects in Colarado, 1989-1998. Public Health 2002; 116: 89-94.

14. Muthinick O, Orozco E, Lisker R, et al. Risk factors associated with neural tube defects: exposure during the first trimester of gestation. Gaceta Medica de Mexico 1996;126: 227-3

15. Lynberg MC, Khoury MJ, Lu X, et al. Maternal flu, fever, and the risk of tube defects: a population-based case-control study. Am J Epidemiol 1994; 140: 244-255

16. Richards ID. Congenital malformations and environmental influences in pregnancy. Br $\mathrm{j}$ Prev Soc Med 1969; 23: 218-225

17. Rasmussen AS, Chu SY, Kim SY, et al. Maternal obesity and risk of neural tube defects: a metaanalysis. Am J Obstet Gynecol 2008; 198(6): 611-619

18. Suarez L, Felkner M, Brender JD, et al. Maternal exposures to cigarette smoke, alcohol, and street drugs and neura ltube defect occurrence in offspring. Matern Child Health J 2008;12: 394401

19. Behrman ER, Kliegman RM, Jenson HB. Nelson Textbook of Pediatrics, 17 thEdition 2004: 1983-1987

20. Mitchell LE, Adzick SN, Melchionne J, etal. Spina bifida. Lancet 2004; 364:1885-95

21. Berg KF, Oppen ACCV, Holthe W, Schielen PCJI, et al. Neural tube defects associated with prenatal exposure to antiepileptic drugs. ReproductiveToxicology 2007; 24:57-8032.

22. Li Z, Ren A, Liu J, et al. Maternal flu or fever, medication use, and neural tube defects: A population-based case -control study in northen China. Birth Defects Research (Part A) 2007; 79: 295-300

23. Lynberg MC, Khoury MJ, Lu X, et al. Maternal flu, fever, andthe risk of tube defects: a population-based case-control study. Am J Epidemiol 1994; 140: 244-255

24. Zhang L, Ren AG, Li ZW, et al. Plazma and red blood cell folate level among women in their first trimester of pregnancy from rural areas with high or low prevalance of neural tube defects, China. Zhonghua Liu Xing Bing Xue ZaZhi 2006; 27(8): 659-63

25. Kirke PN, Molloy AM, Daly LE, et al. Maternal plasma folate and vitamin B12 are independent risk factors for neural tube defects. Q J Med 1993; 86(11): 703-8
26. Groenen PMW, Rooij IALMV, Peer PGM, at al. Marginal maternal vitamin B12 status increases the risk of off spring with spina bifida. American Journal of Obstetrics and Gynecology 2004; 191: 11-7

27. Adams MJ, Khoury MJ, Scanlon KS, etal. Elevated midtrimester serum methylmalonicacid levels as a risk factor for neural tube defects. Teratology 1995; 51(5): 311-7 67

28. Vander put NM, Thomas CMG, Eskes TKAB, et al. Altered folate and vitamin B12 metabolism in families with spina bifida offspring. Q J Med 1997; 90: 505-510

29. Schorah C J, Smithells RW, Scott J. Vitamin B12 and anencephaly. Lancet 1980;19: 880

30. Ray J G, Wyatt P R, Miles D T, Marian J V, Cris M, Pui-Yuen W, Sandra A F, David ECC. Vitamin B12 and the risk of neural tube defects in a folic-acid -fortified population. Epidemiology 2003; 18(3): 362-366 